See discussions, stats, and author profiles for this publication at: https://www.researchgate.net/publication/327383899

\title{
Diversity and activity of soil fauna in an industrial settling pond managed by natural attenuation
}

Article in Applied Soil Ecology · September 2018

DOI: 10.1016/j.apsoil.2018.08.020

CITATIONS

0

8 authors, including:

Hermine Huot

Sun Yat-Sen University

24 PUBLICATIONS 196 CITATIONS

SEE PROFILE

Françoise Watteau

University of Lorraine

60 PUBLICATIONS 476 CITATIONS

SEE PROFILE
Jérôme Cortet

Paul Valéry University, Montpellier 3

112 PUBLICATIONS 1,701 CITATIONS

SEE PROFILE

(1.) Vittoria Milano

Paul Valéry University, Montpellier 3

7 PUBLICATIONS 5 CITATIONS

SEE PROFILE

Some of the authors of this publication are also working on these related projects:

Book chapters : Soils within Cities - Global approaches to their sustainable management. Catean 2017. Editors : MJ Levin, KHJ Kim, W Burghart, P Charzynski, RK Shaw View project

Assessing the impact of keystone Lumbricid earthworms (keystone species) on greenhouse gasses, soil quality, water fluxes, carbon sequestration and productivity in an agricultural context - a multifunctional approach. View project 


\title{
Diversity and activity of soil fauna in an industrial settling pond managed by natural attenuation
}

\author{
H. Huot ${ }^{\mathrm{a}, \mathrm{b}, \mathrm{c}, *}$, J. Cortet ${ }^{\mathrm{b}, \mathrm{c}, \mathrm{d}}$, F. Watteau ${ }^{\mathrm{b}, \mathrm{c}, \mathrm{e}}$, V. Milano ${ }^{\mathrm{d}}$, J. Nahmani ${ }^{\mathrm{d}, \mathrm{f}}$, C. Sirguey ${ }^{\mathrm{b}, \mathrm{c}}$, \\ C. Schwartz ${ }^{\mathrm{b}, \mathrm{c}}$, J.L. Morel ${ }^{\mathrm{b}, \mathrm{c}}$ \\ a School of Environmental Science and Engineering, Sun Yat-sen University, Guangzhou 510275, China \\ ${ }^{\mathrm{b}}$ Université de Lorraine, Laboratoire Sols et Environnement, UMR 1120, 2 avenue de la Forêt de Haye, TSA 40602, 54518, Vandouvre-lès-Nancy, France \\ ${ }^{c}$ INRA, Laboratoire Sols et Environnement, UMR 1120, 2 avenue de la Forêt de Haye, TSA 40602, 54518 Vandouvre-lès-Nancy, France \\ ${ }^{\mathrm{d}}$ CNRS - Université de Montpellier - Université Paul Valéry Montpellier 3 - EPHE-, Centre d'Ecologie Fonctionnelle et Evolutive, UMR 5175, route de Mende, 34199 \\ Montpellier Cedex 5, France \\ e CNRS, UMS 3562, 15 rue Notre-Dame des Pauvres, BP 20, 54501 Vandoeuvre-lès-Nancy, France \\ ${ }^{\mathrm{f}}$ CNRS - Université de Lorraine, Laboratoire Interdisciplinaire des Environnements Continentaux, UMR 7360, 5 avenue du Charmois, 54500 Vandoeuvre-lès-Nancy, France
}

\section{A R T I C L E I N F O}

\section{Keywords:}

Contaminated site

Metals

Soil fauna

Microstructure

Spontaneous vegetation succession

\begin{abstract}
A B S T R A C T
Forest ecosystems can spontaneously establish themselves on former industrial sites contaminated by metals. The sustainable management of these sites by natural attenuation requires a better understanding of the relationships between soil biodiversity, metals and soil functioning in such ecosystems. In this context, a forest ecosystem growing on iron industry by-products containing potentially toxic metals as major elements was studied using a multiproxy approach including chemical soil properties, microstructure, meso- and macro-fauna. Fauna communities in the topsoil were characterized by a high abundance and taxonomic diversity, but also by an unusual predominance of epigeic and detritivorous species. Fauna community structures were partly explained by the presence not only of heavy metals ( $\mathrm{Zn}, \mathrm{Cd}$ ), but also Fe and Mn, dominant metals in iron industry by-products. The uncommon structure of macrofauna communities could have effects on the soil functioning, such as limiting the incorporation and mixing of organic matter into the soil. Mesofauna communities contributed to the metal redistribution in the soil by integrating metals into organo-mineral associations. In terms of management, this study showed the feasibility of using natural attenuation to manage sites with high metal contents but low metal availability and favorable conditions for plant growth. However, the influence of soil biota on metal mobility and soil functioning needs to be further investigated in order to assess the sustainability of such management.
\end{abstract}

\section{Introduction}

After the closure of heavy industrial production facilities in parts of Europe at the end of the 20th century, ecosystems have been able to recover on some highly-contaminated brownfield land, leading in some situations to dense forest ecosystems. Usually these sites are considered as derelict areas that need to be reclaimed because of the high contaminant levels, especially of metals. Natural attenuation is not often considered for the management of such contaminated sites, although it may represent a valuable and cost-effective solution. Depending on the objectives of the restoration, i.e. development of ecosystem services, the use of natural processes can be advocated for these sites provided that the conditions are not too adverse and it will not generate negative impacts on the surrounding environment, e.g. contamination of water bodies or decrease of the biodiversity (Auclerc, 2017; Bradshaw, 2000; Prach and Hobbs, 2008).

Soil biodiversity of metal-contaminated sites is complex and may or may not reflect the soil total metal content gradients (Caruso et al., 2009; Khalil et al., 2009; Syrek et al., 2006). In some highly contaminated soils, organisms can be observed because metals are not available or organisms have adapted to the presence of metals (Lanno et al., 2004). The impact of contaminants on soil biota is strongly related to their bioavailability, which depends on several factors including soil properties, the sensitivity of species (Nahmani et al., 2007) and avoidance strategy (Gillet and Ponge, 2003). Metal contamination can strongly affect fauna communities, inducing changes in the community structure. These changes in community composition could be partly related to modifications in vegetation and thus in organic matter

\footnotetext{
* Corresponding author at: School of Environmental Science and Engineering - Sun Yat-Sen University, 135, Xingangxi Road, 510275 Guangzhou, PR China.

E-mail address: huot3@mail.sysu.edu.cn (H. Huot).
} 
(OM) quantity and quality caused by soil contamination (Gillet and Ponge, 2002; Nahmani and Lavelle, 2002). In turn, the presence of high quantities and/or a high quality of $\mathrm{OM}$ can also compensate for the potentially deleterious effects of metals on soil fauna communities. For instance, it has been shown that urban soils can support collembolan communities comparable to forest soils despite soil pollution because they were favored by OM accumulation (Santorufo et al., 2015).

Soil biota are involved in the regulation of major soil processes and functions, such as OM decomposition, structure development, water and nutrient cycling. Changes in community structure due to contamination can contribute to the impairment of some functions, such as a slowing down of the OM decomposition rate (e.g. Niemeyer et al., 2012). In addition, through their activities, soil fauna communities can also influence the redistribution, transport and availability of metals in soils. For instance, earthworm activity was shown to increase metal availability and mobility (Blouin et al., 2013; Sizmur and Hodson, 2009).

Thus, the investigation of soil biota and their activity in relation to other ecosystem components (e.g. soil, litter, vegetation) is essential to a better understanding of the formation and the functioning of these new ecosystems and can consequently be used to design sustainable management solutions for these sites (e.g. Frouz et al., 2008).

Abandoned settling ponds containing sludge rich in potentially toxic metals produced during the iron-making process are common in areas with a history strongly linked to the steel or iron industries. After the closure of industrial facilities, some ponds were covered by inert materials, topsoil or geomembranes, while others were left uncovered and evolved under the action of natural factors, leading for some, to the development of forest ecosystems over a few decades. Relationships between soil biodiversity and soil functioning in such newly-forested ecosystems established on purely anthropogenic metal-rich materials have rarely been studied (Lucisine et al., 2015).

This study focused on a spontaneously-forested settling pond on a former iron-production site, which was investigated using an original multiproxy approach combining the identification of both soil macroand mesofauna communities, soil micromorphology and an analysis of the soil chemical properties. The specific objectives were i) to identify the fauna communities living within the surface layers $(0-20 \mathrm{~cm})$ of this soil, ii) to investigate the potential influence of metals on the structure of fauna communities, through multivariate analyses and the determination of metal accumulation in dominant species and iii) to explore the effects of biological activity on the transformation of organic matter, the soil structuration and the redistribution of metals through the observation and the analysis of organo-mineral associations on different scales.

We first hypothesized that soil fauna communities have established themselves despite the metal high concentrations in the soil parent materials, but that taxa living in the surface organic layers resulting from $\mathrm{OM}$ accumulation from vegetation cover, can be favoured over those living deeper in the soil, which are thus more likely to be in direct contact with industrial by-products metals. Indeed, it has been reported that $\mathrm{OM}$ accumulation at the surface of an abandoned contaminated site can create a new less-contaminated layer favouring the recovery of decomposer biota, whereas the underlying highly contaminated horizon displayed a less abundant fauna community with a total absence of some sensitive taxa, which are both orally and dermally in contact with metals (Selonen et al., 2014).

Secondly, regarding the impact of such fauna community on soil functions, we hypothesized that fauna activity can contribute to the mixing of organic matter from the vegetation cover and mineral matter from the industrial by-products, thereby inducing a redistribution of metals, especially in organo-mineral associations. Finally, the results will be discussed in terms of sustainable management regarding the feasibility of using spontaneous vegetation succession to manage such sites.

\section{Material and methods}

\subsection{Study site}

The study was carried out in Frouard (Lorraine, North-East France), in a triangular $(150 \times 250 \times 150 \mathrm{~m})$ settling pond of a former ironworks, situated on an island, at the confluence of the Meurthe and Moselle rivers (Fig. S1). This pond was used for storing blast furnace sludge probably until the mid- $20^{\text {th }}$ century. The geology consisted of a marly substratum covered by alluvia of both rivers on which sludge was dumped, generating deposits of around $10 \mathrm{~m}$ in depth.

After the cessation of dumping, vegetation has developed spontaneously leading to the establishment of a species-rich plant community typical of mesohygrophilic deciduous forest (Lucisine et al., 2015). The tree layer was dominated by the pioneer species Betula pendula and included Populus tremula, Carpinus betulus, Fagus sylvatica, Fraxinus excelsior, Quercus robur, Tilia sp. About ten species of shrubs have been identified, including Cornus sanguinea, Crataegus monogyna, Euonymous europaeus, Prunus avium, Sambucus nigra, as well as Acer platanoides, Acer pseudoplatanoides, and Ulmus campestris. The tree layer was more or less dense across the settling pond, creating small clearings with varying herbaceous and ground-cover plants. More than 30 species of herbaceous plants have been observed, especially Galium aparine, Geum urbanum, Hedera helix, Lamium maculatum, Reynoutria japonica, Rubus sp. or Urtica dioica. Most of the species were typical of soils with a nearneutral $\mathrm{pH}$ (neutrocline). Some were adapted to wet soils (hydrocline to mesohygrophilic) and others to soils particularly rich in nutrients including $\mathrm{N}$ (neutronitrocline to nitratophilous), such as L. maculatum or U. dioica (Rameau et al., 1989). No particular metal-hyperaccumulating plant species were observed on the site. In the central part of the settling pond, tree height reached 15 to $30 \mathrm{~m}$, according to measurements done five years after the study referred to. The determination of tree age for ten species showed that some trees started to grow in the early 1970s. However, individuals of the dominant tree species (B. pendula, $P$. tremula) have mainly developed since the early 1990s (data unpublished, personal communication of F. Maunoury-Danger). The embankment delimiting of the pond on the western part was reprofiled to upgrade the road and planted with locusts (Robinia pseudoacacia) in 1997. The northern and eastern parts of the pond were delimited by the fence of a new factory built in the 1990s during the economic reconversion of the area. The vegetation of the southern part was more dispersed among concrete debris and dominated by $B$. pendula.

The soil had an A/C profile showing the superimposition of different layers resulting from the settling of successive inputs of sludge and the development of holorganic and organo-mineral horizons at the surface (Fig. S2; Huot et al., 2014a; Schwartz et al., 2001). The thickness of the holorganic horizon varied across the site $(1-10 \mathrm{~cm})$ depending on the vegetation; being thicker under the tree layer and thinner under the herbaceous layer including $R$. japonica. The soil was characterized by a varying vertical elemental composition dominated by $\mathrm{Si}, \mathrm{Ca}, \mathrm{Al}, \mathrm{Fe}, \mathrm{Mn}$ as well as $\mathrm{Pb}$ and $\mathrm{Zn}$, which can be considered to be the major elements. The $\mathrm{pH}$ was slightly alkaline, with high concentrations of carbonates and a high cationic exchange capacity, saturated by $\mathrm{Ca}^{2+}$. These fine materials had a high porosity and water retention capacity (Fig. S2). As consequence, the soil was described as a Spolic Technosol (Andic, Calcaric, Hydric, Laxic, Thixotropic, Toxic) according to the World Reference Base for Soil Resources (Huot et al., 2013).

Fauna, microstructure and soil properties were studied within the former settling pond to avoid border effects using a general grid $(15 \times 7.5 \mathrm{~m})$ (Fig. S1C), as detailed in the following parts.

\subsection{Identification and analysis of soil fauna communities}

\subsubsection{Meso- and macrofauna diversity}

Microarthropods were studied on 66 soil cores $(0-5 \mathrm{~cm}$ depth, $5 \mathrm{~cm}$ diameter) collected using the $7.5 \times 15 \mathrm{~m}$ grid after removal of the fresh 
litter (Fig. S1C). Microarthropods were extracted using the Macfayden method over a period of a week (Cortet et al., 2007) and sorted using a dissecting stereomicroscope. Adult mites were identified to the order or cohort level (Trombidiformes, Mesostigmata, Astigmatina and Oribatida) (Krantz, 1978; Krantz and Walter, 2009). When possible, collembolans were identified at the species level using different keys (Bretfeld, 1999; Gisin, 1960; Potapov and Dunger, 2001). All other microarthropods (e.g. pseudoscorpions, small millipeds) were grouped together. The abundance of each taxon was assessed for each sampling point, and the Collembola species richness for each sample and for the global site. Collembola species diversity and evenness were also calculated using the Shannon and Pielou indices respectively.

Macroinvertebrates were sampled from 20 selected points of the grid, using a $15 \times 15 \mathrm{~m}$ pattern (Fig. S1C). At each point, a soil core $(25 \times 25 \times 20 \mathrm{~cm})$ was excavated after the removal of the fresh litter and macroinvertebrates were manually extracted and identified using binocular at the family level, except for Diplopoda and earthworms, which were identified at the species level. Adults (Ad) and larvae (L) were distinguished for Coleoptera.

\subsubsection{Metal contents in fauna}

As predominant class of the macrofauna community, Diplopoda were analyzed for metal content, which was determined for the three most abundant species (Cylindroiulus punctatus, Julus scandinavius, Polydesmus angustus). After $12 \mathrm{~h}$ of gut voiding in a Petri dish on a moist Waterman paper filter, individuals were rinsed with deionised water and frozen at $-20^{\circ} \mathrm{C}$. Diplopods were dried at $45^{\circ} \mathrm{C}$ for $72 \mathrm{~h}$, then weighed and dissolved in $2 \mathrm{~mL}$ of $\mathrm{HNO}_{3}(68 \%)$ at room temperature for $4 \mathrm{~h}$ and at $80^{\circ} \mathrm{C}$ for $24 \mathrm{~h}$. After cooling, they were digested in $2 \mathrm{~mL} \mathrm{H}_{2} \mathrm{O}_{2}$ $(30 \% \mathrm{v} / \mathrm{v})$ for at least $2 \mathrm{~h}$ at room temperature and then $4 \mathrm{~mL}$ of deionized water was added. After filtration at $0.45 \mu \mathrm{m}$, solutions were adjusted to $10 \mathrm{~mL}$ with deionised water (Addison and Holmes, 1995). Concentrations of $\mathrm{Cd}, \mathrm{Zn}, \mathrm{Cu}$ and $\mathrm{Pb}$ were measured using ICP-AES. Blanks were performed and biological standard reference material (mussel tissue, NCS ZC 78005GBW08571, Promochem, Teddintgon, UK) was used as a control. A maximal relative error of $5 \%$ compared to the certified values was accepted.

\subsection{Soil properties}

\subsubsection{Microstructure of the surface layers}

Microstructure of the surface soil horizons was studied at three locations within the $15 \times 15 \mathrm{~m}$ grid displaying varying thicknesses of the holorganic horizon (Fig. S1C). Undisturbed soil samples were collected in the $0-10 \mathrm{~cm}$ soil horizon using Kubiena boxes $(9 \mathrm{~cm} \times 6 \mathrm{~cm} \times 4.5 \mathrm{~cm})$ after the removal of the fresh litter. After extraction from the soil, the boxes were wrapped and secured against any disturbance prior to being transported. The soils were air-dried and then impregnated with resin (Norsodine $2983 \mathrm{~V}$ ). Two thin $20-\mu \mathrm{m}$ sections were prepared. Sections were observed with a Leica MZ FLIII stereomicroscope (magnification $\times 8$ to $\times 100$ ). Morphology, size, and constitution of fecal patterns allowed the identification of some animal groups according to the classification of Bullock et al. (1985). Selected pieces of the soil thin sections were carbon-coated and characterized by a JEOL J7600F scanning electron microscope (SEM) (15 kV) equipped with an EDS system. For comparison purposes, additional images of thin sections from deeper mineral layers $(25-35 \mathrm{~cm})$ collected along the soil profile (Huot et al., 2014a) were used.

\subsubsection{Agronomic parameters and metal distribution of the surface layers}

Total metal concentrations ( $\mathrm{Al}, \mathrm{Cu}, \mathrm{Cd}, \mathrm{Fe}, \mathrm{Mn}, \mathrm{Pb}, \mathrm{Zn}$ ) of the surface layers were assessed at the same 20 points of the $15 \times 15 \mathrm{~m}$ grid as the macroinvertebrates, and part of the mesofauna were sampled (see 2.2.1). Soil cores $(25 \times 25 \mathrm{~cm})$ were excavated within the first $20 \mathrm{~cm}$ of the soil surface layers after the removal of the fresh litter. Total metal concentrations were determined on 50-g subsamples after air-drying and sieving at $2 \mathrm{~mm}$ by INRA (Laboratory of soil analyses, Arras, France) using ICP-OES for $\mathrm{Cu}, \mathrm{Fe}, \mathrm{Mn}, \mathrm{Zn}$ and $\mathrm{Al}$ and ICP-MS for $\mathrm{Pb}$ and Cd (NF EN ISO 11885).

Agronomic properties and total metal concentrations of the organomineral horizon were determined at the same three locations and at a similar depth to the Kubiena boxes (see 2.3.1). The organo-mineral horizon was analyzed for the following parameters by INRA (Laboratory of soil analyses, Arras, France): organic C and total $\mathrm{N}$ by dry combustion (NF ISO 10,694 and NF ISO 13878), extractable P using Olsen method (NF ISO 11263), $\mathrm{pH}_{\text {water }}(1 / 5 \mathrm{v} / \mathrm{v}$ ) (NF ISO 10390), total carbonates (NF ISO 10693) and total metal concentrations by $\mathrm{HF}^{-\mathrm{HClO}_{4}}$ digestion (NF X 31-147) and analysis using ICP-AES (Al, Fe, Mn, Mg, K, $\mathrm{Zn})$ and ICP-MS (Cd, Pb).

\subsection{Statistics}

To evaluate the effects of soil metal concentrations (Al, $\mathrm{Cd}, \mathrm{Cu}, \mathrm{Fe}$, $\mathrm{Mn}, \mathrm{Pb}, \mathrm{Zn}$ ) on macrofauna and collembolan species abundances, nonparametric and multivariate analyses were used, according to the nonnormal distribution of data (i.e. macrofauna taxa and collembolan species). Two Non-Metric Multidimensional Scaling (NMDSs) were carried out separately on macrofauna and collembolan species assemblages, based on Bray-Curtis distance matrices, two axes, and 9999 iterations. Generalized Additive Models (GAMs) were fitted a posteriori to the NMDS spaces using the restricted maximum likelihood estimation method (REML) for the smooth component selection (Marra and Wood, 2011). The analyses were performed within the $\mathrm{R} 3.0 .1$ programming environment (R Core Team, 2013) using functions from the "vegan" (Oksanen, 2016) and "lmtest" (Hothorn et al., 2017) packages.

\section{Results}

\subsection{Characterization of the upper soil layers}

Soil sections of upper layers showed the presence of a holorganic layer of varying thickness (up to $10 \mathrm{~cm}$ ), overlying the organo-mineral layer (Fig. 1A). Some plant organic matter from leaf, branch or root origin was observed as individual fresh materials (Fig. 1B). Others were fragmented to finer tissue residues (Fig. $1 \mathrm{~A}$ and $\mathrm{B}$ ) or associated into aggregates (Fig. 1C). The proportion of organo-mineral aggregates increased gradually when looking at the lower layer of the section (Fig. 1A). Underlying layers $(25-35 \mathrm{~cm}$ ) were mainly mineral and root sections could be observed (Fig. 1D). Organic matter was also present in the cracks, in the form of more or less degraded tissues (Fig. 1E), or closely associated to minerals as aggregates from the upper layer (Fig. 1F).

Analyses of the organo-mineral horizon showed that this was characterized by high concentrations of organic $\mathrm{C}$, total $\mathrm{N}$ and $\mathrm{P}$ with a $\mathrm{C}: \mathrm{N}$ ratio of 16 . It had a slightly alkaline $\mathrm{pH}$ in relation to quite high carbonate contents. The contents of metals, like $\mathrm{Al}, \mathrm{Fe}, \mathrm{Mn}$ but also $\mathrm{Pb}$ and $\mathrm{Zn}$, reached several percent. Other trace metallic elements, such as $\mathrm{Cd}$, were also present in high concentration $(\mathrm{n}=3$, Table 1$)$. The distribution of metal concentrations in the first $20 \mathrm{~cm}$ of the soil varied across the site (coefficients of variation: $78 \%$ for $\mathrm{Fe}, 57 \%$ for $\mathrm{Mn}, 48 \%$ for $\mathrm{Pb}, 51 \%$ for $\mathrm{Cd}, 38 \%$ for $\mathrm{Zn}, 31 \%$ for $\mathrm{Cu}, 19 \%$ for $\mathrm{Al}, \mathrm{n}=20$ ).

\subsection{Soil fauna community composition and diversity}

\subsubsection{Mesofauna}

The mean total abundance of microarthropods per square meter was $18737 \pm 17263$, with a community dominated by Collembola, representing $55 \%$ of microarthropods (Table 2). Oribatida, Prostigmata and Mesostigmata represented respectively $25 \%, 9 \%$ and $4 \%$ of total microarthropods. Other small arthropods (e.g. pseudoscorpions, spiders, millipeds) represented $7 \%$ of the total community. The Acari/ Collembola ratio was 0.7 . 

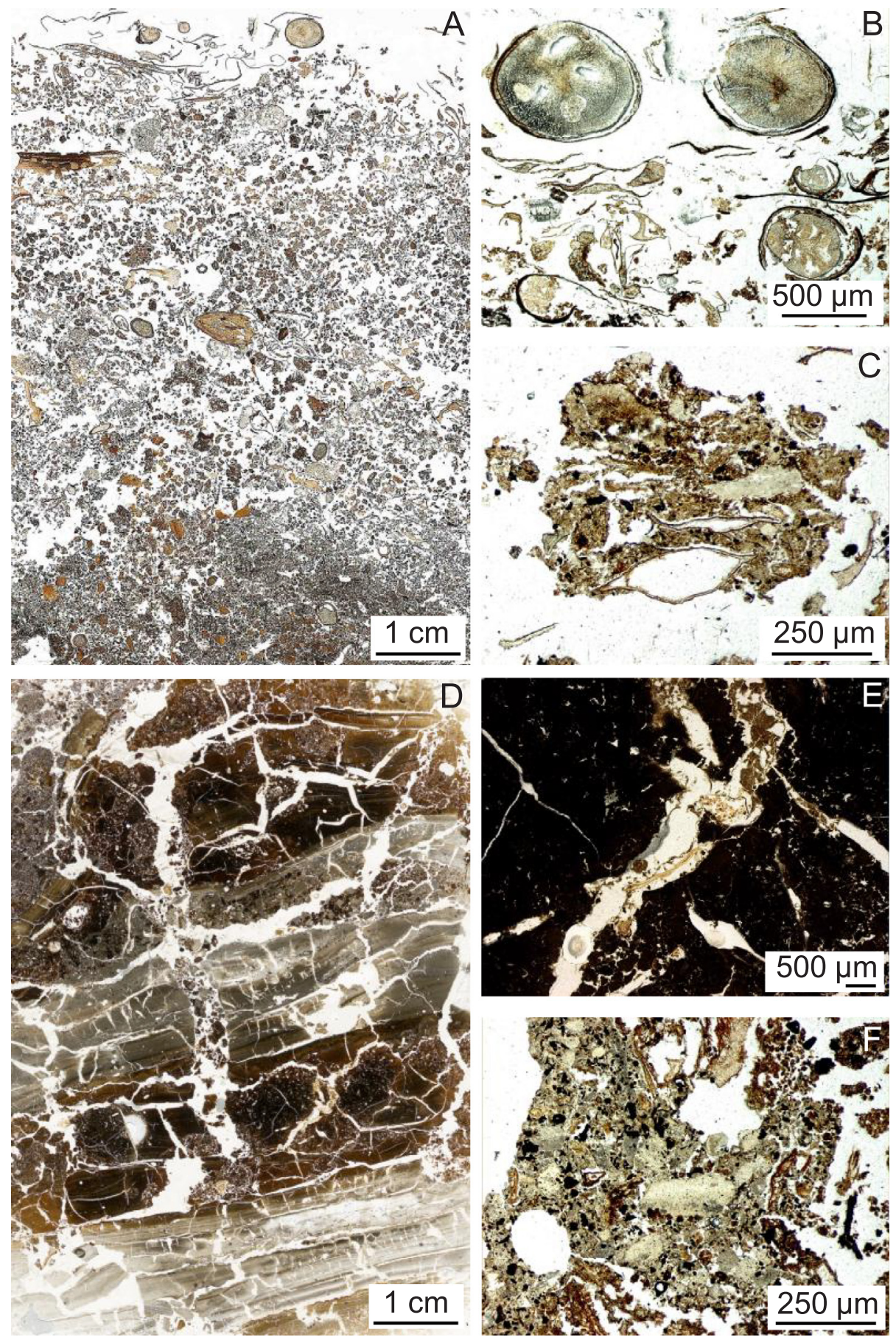

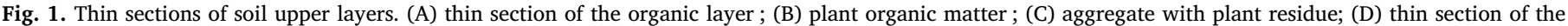
underlying organo-mineral layers $(25-35 \mathrm{~cm})$; (E) organic matter in cracks; (F) organo-mineral aggregates.

The Collembola community was represented by 30 species, dominated by three taxa, Parisotoma notabilis, Mesaphorura sp. (including at least the two species Mesaphorua sylvatica and Mesaphorura krausbaueri) and Cryptopygus thermophilus representing respectively 34\%, 29\% and $18 \%$ of the total Collembola abundance. The mean Collembola species richness per sample was 5.76. The alpha diversity of Collembola was characterized by a mean Shannon index of 1.95 and an eveness of 0.80 . Hemi-edaphic Collembola represented $57 \%$ of Collembola, followed by $38 \%$ of eu-edaphic and $5 \%$ of epi-edaphic Collembola (Table 2).

\subsubsection{Macrofauna}

A total of 956 macroinvertebrates were collected from the 20 soil cores, with a mean density of 765 ind. ${ }^{-2}$. Macroinvertebrates mainly lived in the litter layer with $65 \%$ of the community represented by epigeic species. Saprophagous, predacious and phytophagous represented respectively 54,37 and $9 \%$ of total macroinvertebrates. While Diplopoda representing $40 \%$ of macroinvertebrates, earthworms were the least abundant group, representing only $2 \%$ of the total community abundance (Fig. 2). Among Diplopoda, three Julidae species (Cylindroiulus punctatus, Julus scandinavius, Ommatoiulus sabulosus), one Polydesmidae (Polydesmus angustus) and one Chordeumatidae (Melogona gallica) were collected. C. punctatus represented $89 \%$ of Diplopoda. 
Table 1

Agronomic properties and total major element and metal concentrations of the organo-mineral horizon. The parameters were measured on three sites across the settling pond (mean \pm standard deviation).

\begin{tabular}{lll}
\hline & Agronomic parameters & \\
\hline $\mathrm{pH}$ & - & $8.0 \pm 0.1$ \\
organic C & $\mathrm{g} \mathrm{kg}^{-1}$ & $88 \pm 20$ \\
total N & $\mathrm{g} \mathrm{kg}^{-1}$ & $5.5 \pm 1.5$ \\
$\mathrm{C} / \mathrm{N}$ & - & $16 \pm 0.8$ \\
$\mathrm{CaCO}_{3}$ & $\mathrm{~g} \mathrm{~kg}^{-1}$ & $125 \pm 56$ \\
$\mathrm{P}_{2} \mathrm{O}_{5}$ & $\mathrm{~g} \mathrm{~kg}^{-1}$ & $0.07 \pm 0.02$ \\
& $\mathrm{Elemtal} \mathrm{composition}$ & \\
$\mathrm{Al}$ & $\%$ & $4.1 \pm 0.4$ \\
$\mathrm{Ca}$ & $\%$ & $7.3 \pm 2.2$ \\
$\mathrm{Fe}$ & $\%$ & $8.1 \pm 2$ \\
$\mathrm{~K}$ & $\%$ & $0.4 \pm 0.2$ \\
$\mathrm{Mg}$ & $\%$ & $1.0 \pm 0.3$ \\
$\mathrm{Mn}$ & $6.3 \pm 2.3$ \\
$\mathrm{Cd}$ & $\%$ & $90 \pm 75$ \\
$\mathrm{Cr}$ & $\mathrm{mg} \mathrm{kg}$ & $129 \pm 41$ \\
$\mathrm{Cu}$ & $\mathrm{mg} \mathrm{kg}$ & $177 \pm 42$ \\
$\mathrm{Ni}$ & $\mathrm{mg} \mathrm{kg}$ & $58 \pm 6$ \\
$\mathrm{~Pb}$ & $\mathrm{mg} \mathrm{kg}$ & $30233 \pm 16799$ \\
$\mathrm{Zn}$ & $\mathrm{mg} \mathrm{kg}^{-1}$ & $28633 \pm 24549$ \\
\hline & $\mathrm{mg} \mathrm{kg}$ & \\
\hline
\end{tabular}

\subsection{Relationships between metals and biological diversity and activity}

\subsubsection{Metals in biostructures and in macrofauna}

As shown in Fig. 1, plant organic matter presented different levels of degradation, ranging from fresh materials to fine residues. Soil section observations also showed many areas with fecal pellets (Fig. 1A and Fig. 3A-C). The presence of these fecal patterns gave this layer a granular structure preserving many voids. Their size and holorganic nature was congruent with the presence of Isopoda and Diplopoda. Fecal pellets attributed to oribatid mites were still observed in plant residues (Fig. 3B), and presented both organic and mineral parts (SEM view, Fig. 3D). Analyses by SEM-EDS of these pellets showed that organic material was mainly associated with $\mathrm{Ca}$, while $\mathrm{Zn}, \mathrm{Pb}$ and $\mathrm{Mn}$ were associated with mineral material (Fig. 3E and F).

Metal concentrations in three species of Diplopoda varied from 71 to $429 \mathrm{mg} \mathrm{kg}^{-1}$ for $\mathrm{Cu}, 46$ to $743 \mathrm{mg} \mathrm{kg}^{-1}$ for $\mathrm{Pb}$ and 227 to $1380 \mathrm{mg} \mathrm{kg}^{-1}$ for $\mathrm{Zn}$. Concentrations in $\mathrm{Zn}$ tended to be higher in $P$. angustus than for the other species (C. punctatus, J. scandinavius) (Table 3). Cadmium was not detected in Diplopoda.

3.3.2. Relationship between surface soil metal concentrations and fauna community assemblages

Generalized additive models based on soil total Zn $(p<0.01)$, Mn

Table 2

Abundance and diversity of microarthropods in the settling pond $(n=66)$.

\begin{tabular}{|c|c|c|c|c|c|c|c|c|c|}
\hline & & & Mean & St. Dev. & Median & Min. & Max. & Quart. 1 & Quart. 3 \\
\hline \multirow[t]{4}{*}{ Abundance $^{1}$ mites } & Oribatida & & 4716 & 6796 & 3537 & 0 & 53,414 & 1769 & 5306 \\
\hline & Prostigmata & & 1683 & 1141 & 1415 & 354 & 6721 & 1061 & 2122 \\
\hline & Mesostigmata & & 788 & 1742 & 354 & 0 & 14,149 & 88 & 1061 \\
\hline & Astigmata & & 48 & 277 & 0 & 0 & 2122 & 0 & 0 \\
\hline \multirow[t]{8}{*}{ Abundance $^{1}$ epi-edaphic Collembola } & Isotoma & Iso_sp & 21 & 85 & 0 & 0 & 354 & 0 & 0 \\
\hline & Isotoma viridis & I_vir & 75 & 220 & 0 & 0 & 1061 & 0 & 0 \\
\hline & Entomobrya sp. & $\overline{E n t} s p$ & 27 & 113 & 0 & 0 & 707 & 0 & 0 \\
\hline & Lepidocyrtus sp. & Lep_sp & 102 & 213 & 0 & 0 & 1061 & 0 & 0 \\
\hline & Lepidocyrtus lignorum & L_lig & 198 & 323 & 0 & 0 & 1061 & 0 & 354 \\
\hline & Tomocerus vulgaris & $T_{-} v u l$ & 16 & 74 & 0 & 0 & 354 & 0 & 0 \\
\hline & Dicyrtoma minuta & $D_{-} \min$ & 32 & 120 & 0 & 0 & 707 & 0 & 0 \\
\hline & Total epi-edaphic & & 472 & 482 & 354 & 0 & 1415 & 0 & 707 \\
\hline \multirow[t]{13}{*}{ Abundance $^{1}$ hemi-edaphic Collembola } & Folsomia quadrioculata & $F_{-} q u a$ & 118 & 740 & 0 & 0 & 5660 & 0 & 0 \\
\hline & Parisotoma notabilis & P_not & 3414 & 3380 & 2476 & 0 & 19,102 & 1415 & 4422 \\
\hline & Cryptopygus thermophilus & C_the & 1790 & 2242 & 1061 & 0 & 11,319 & 354 & 2741 \\
\hline & Proisotoma minima & $P_{-}$mini & 38 & 197 & 0 & 0 & 1415 & 0 & 0 \\
\hline & Proisotoma minuta & $P_{-}$minu & 5 & 44 & 0 & 0 & 354 & 0 & 0 \\
\hline & Pseudosinella alba & $P_{-} a l b$ & 38 & 110 & 0 & 0 & 354 & 0 & 0 \\
\hline & Friesea sp. & Fri_sp & 5 & 44 & 0 & 0 & 354 & 0 & 0 \\
\hline & Hypogastrura manubrialis & H_man & 198 & 737 & 0 & 0 & 4952 & 0 & 0 \\
\hline & Odontella lamellifera & O_lam & 16 & 97 & 0 & 0 & 707 & 0 & 0 \\
\hline & Xenylla sp. & $X e n_{-} s p$ & 5 & 44 & 0 & 0 & 354 & 0 & 0 \\
\hline & Sminthurinus elegans & S_ele & 155 & 292 & 0 & 0 & 1415 & 0 & 354 \\
\hline & Sphaeridia pumilis & S_pum & 27 & 179 & 0 & 0 & 1415 & 0 & 0 \\
\hline & Total hemi-edaphic & & 5810 & 4105 & 4599 & 354 & 21,931 & 3184 & 7782 \\
\hline \multirow[t]{12}{*}{ Abundance $^{1}$ eu-edaphic Collembola } & Isotomiella minor & I-min & 150 & 785 & 0 & 0 & 6013 & 0 & 0 \\
\hline & Isotomodes productus & I_pro & 11 & 87 & 0 & 0 & 707 & 0 & 0 \\
\hline & Folsomia candida & $F_{-} c a n$ & 16 & 74 & 0 & 0 & 354 & 0 & 0 \\
\hline & Cryptopygus scapelliferus & $\bar{C} \_s c a$ & 16 & 97 & 0 & 0 & 707 & 0 & 0 \\
\hline & Mesaphorura sp. & Mes_sp & 2272 & 3232 & 1415 & 0 & 19,102 & 707 & 2034 \\
\hline & Mesaphorura krausbaueri & $M_{-} k r a$ & 113 & 497 & 0 & 0 & 3537 & 0 & 0 \\
\hline & Mesaphorua macrochaet & $M_{-}$mac & 643 & 1062 & 354 & 0 & 5306 & 0 & 1061 \\
\hline & Mesaphorura sylvatica & $\bar{M}$ syl & 48 & 185 & 0 & 0 & 1061 & 0 & 0 \\
\hline & Protaphorura armata & P_am & 172 & 435 & 0 & 0 & 2122 & 0 & 0 \\
\hline & Arrhopalites caecus & $A_{-} c a e$ & 5 & 44 & 0 & 0 & 354 & 0 & 0 \\
\hline & Megalothorax minimus & $\bar{M}_{-} \min$ & 423 & 1363 & 0 & 0 & 10,258 & 0 & 354 \\
\hline & Total eu-edaphic & & 3870 & 5185 & 2122 & 0 & 33,605 & 1415 & 4245 \\
\hline Total abundance $^{1}$ Collembola & & & 10,152 & 7448 & 7959 & 707 & 40,679 & 5394 & 12,292 \\
\hline Abundance $^{1}$ Other Arthropods $(<2 \mathrm{~mm})$ & & & 1351 & 2380 & 884 & 0 & 18,040 & 354 & 1326 \\
\hline Species richness ${ }^{2}$ Collembola & & & 5.76 & 1.72 & 6.00 & 2.00 & 10.00 & 5.00 & 7.00 \\
\hline Species diversity ${ }^{3}$ Collembola & & & 1.95 & 0.46 & 2.03 & 0.91 & 2.85 & 1.63 & 2.28 \\
\hline Eveness $^{3}$ Collembola & & & 0.80 & 0.11 & 0.81 & 0.48 & 1.00 & 0.73 & 0.89 \\
\hline
\end{tabular}

1 Number of animals per square meter.

2 Number of species per sample (Lepidocyrtus species and Mesaphorura species were respectively considered as one taxon each).

${ }^{3}$ Shannon index calculated per sample (Lepidocyrtus species and Mesaphorura species were respectively considered as one taxon each). 


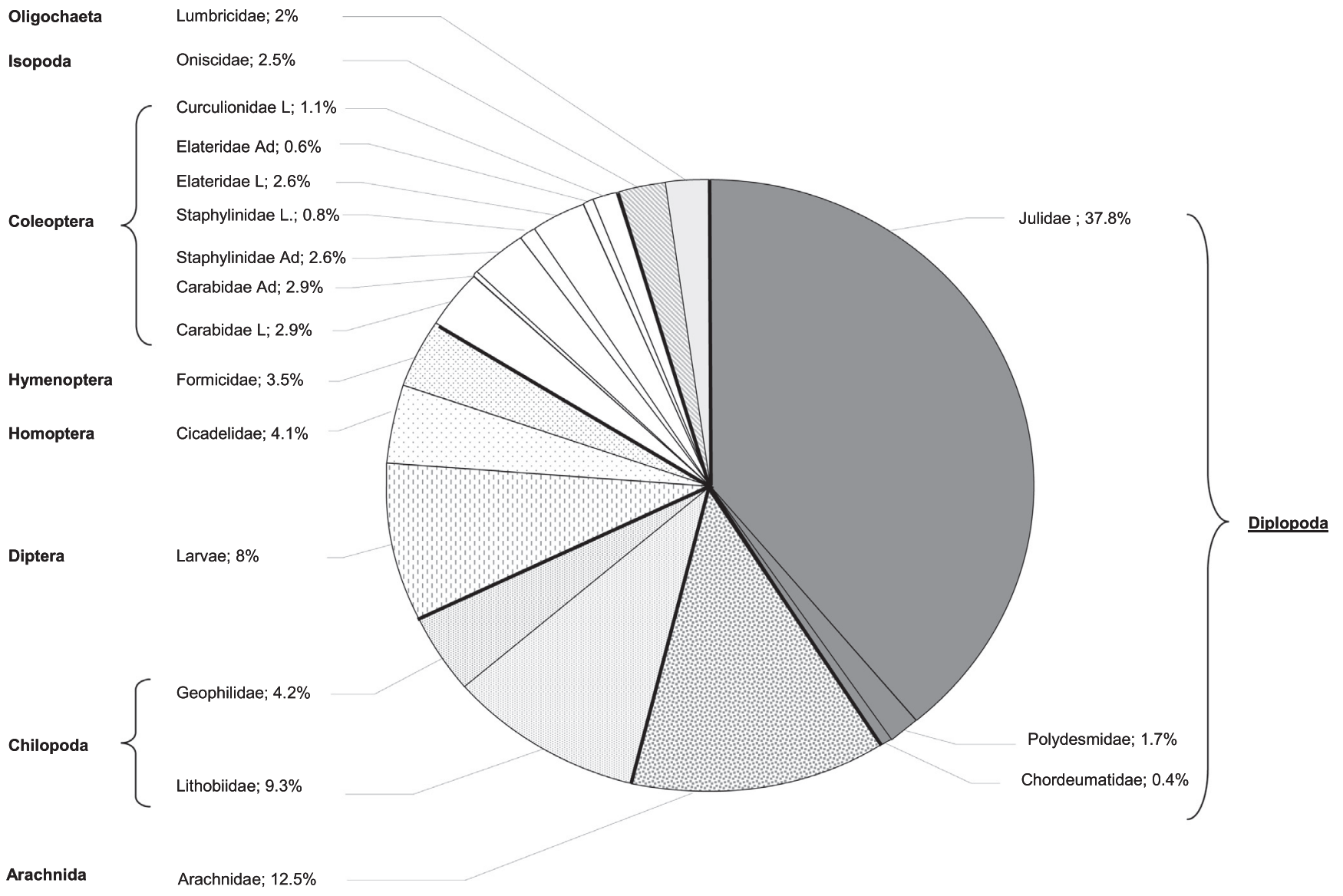

Fig. 2. Relative abundance of macroinvertebrate families collected across the settling pond $(n=20)$. L: larvae; Ad: adult.

$(p<0.05)$ and $\mathrm{Cd}(p<0.05)$ concentrations were significant in modelling macrofauna taxa distribution in the NMDS space (Fig. 4; REML scores: 201.93; 220.49; 101.01; respectively). These GAMs explained $64 \%, 55 \%$ and $42 \%$ of the variance observed, respectively. Complex gradients were observed for $\mathrm{Zn}$ and $\mathrm{Mn}$ concentrations, whereas a nearly linear one was observed for Cd concentrations. Clear macrofauna patterns were identified with Polydesmidae, Lumbricidae and Oniscidae associated with soils with the lowest $\mathrm{Zn}$ and Mn concentrations (Fig. 4A and B). Staphylinidae (L and Ad), Elateridae (L), Curculionidae (L), Geophilidae, Julidae, Araneae, Formicidae and Diptera (L) were specifically found in topsoils with the highest $\mathrm{Zn}$ concentration, and Formicidae, Staphylinidae (L), Carabidae (L), Geophilidae, and Curculionidae (L) were specifically found in those with the highest Mn concentration. Polydesmidae, Elateridae (Ad), Oniscidae and Formicidae were associated with the soils with the lowest $\mathrm{Cd}$ concentration, and Geophilidae, Curculionidae (L), Elateridae (L), Carabidae (L) and Staphylinidae (Ad) were found in the topsoils with the highest $\mathrm{Cd}$ concentration at the opposite end of the gradient (Fig. 4C).

Only the GAM based on soil total Fe concentration $(p<0.05)$ was significant in modelling collembolan species distribution in the NMDS space (Fig. 5; REML score: 62.28 ), explaining $61 \%$ of the variance observed. A pattern was observed showing two areas with increasing $\mathrm{Fe}$ concentrations associated with two different species assemblages: one constituted by Isotomodes productus and Folsomia candida and the other by Dicyrtoma minuta, Isotomiella minor and Entomobrya sp. The other species were mainly present in the topsoils with the lowest Fe concentration (Fig. 5).

\section{Discussion}

4.1. Soil fauna communities in the upper layers of a soil developing on a settling pond of iron industry

The upper layers of the soil developing on a settling pond of an ironworks under forest cover, were characterized by high metal concentrations, but which were also rich in nutrients and organic matter. The organo-mineral layer displayed particularly high concentrations of Cd (50 times greater), $\mathrm{Pb}$ (1000 times greater), and $\mathrm{Zn}$ (250 times greater) than the geochemical background of the alluvial plain of the Moselle river (Custines to Thionville area) (Darmendrail et al., 2000), as well as of Fe ( 3 times greater) and Mn (50 times greater) than the concentrations measured in soils at the periphery of the industrial site (Chaussidon, 1990). This composition was typical of the blast furnace sludge and resulted from iron-making processes (Huot et al., 2013). The surface spatial variation of metal contents can be partly explained by the deposition of the sludge from a unique discharge point. In addition, the changes in the vegetation composition across the pond and thus in the composition and quantity of organic materials could contribute to the spatial heterogeneity of the soil surface composition. When compared to natural soils developed under analogous alluvial forests along the Moselle river, the organo-mineral layer displayed higher concentrations in organic C, in total $\mathrm{N}$, in $\mathrm{P}$, in carbonates, as well as having a higher cationic exchange capacity (Lucisine et al., 2015).

Despite the high metal concentrations, mesofauna communities were well-developed in the upper layers of the Technosol. The abundance, specific richness and diversity of Collembola were comparable to those observed in forested ecosystems but also in some urban and industrial soils (Joimel, 2015). The proportions of eco-morphological groups of Collembola were similar to the ones encountered in non- 

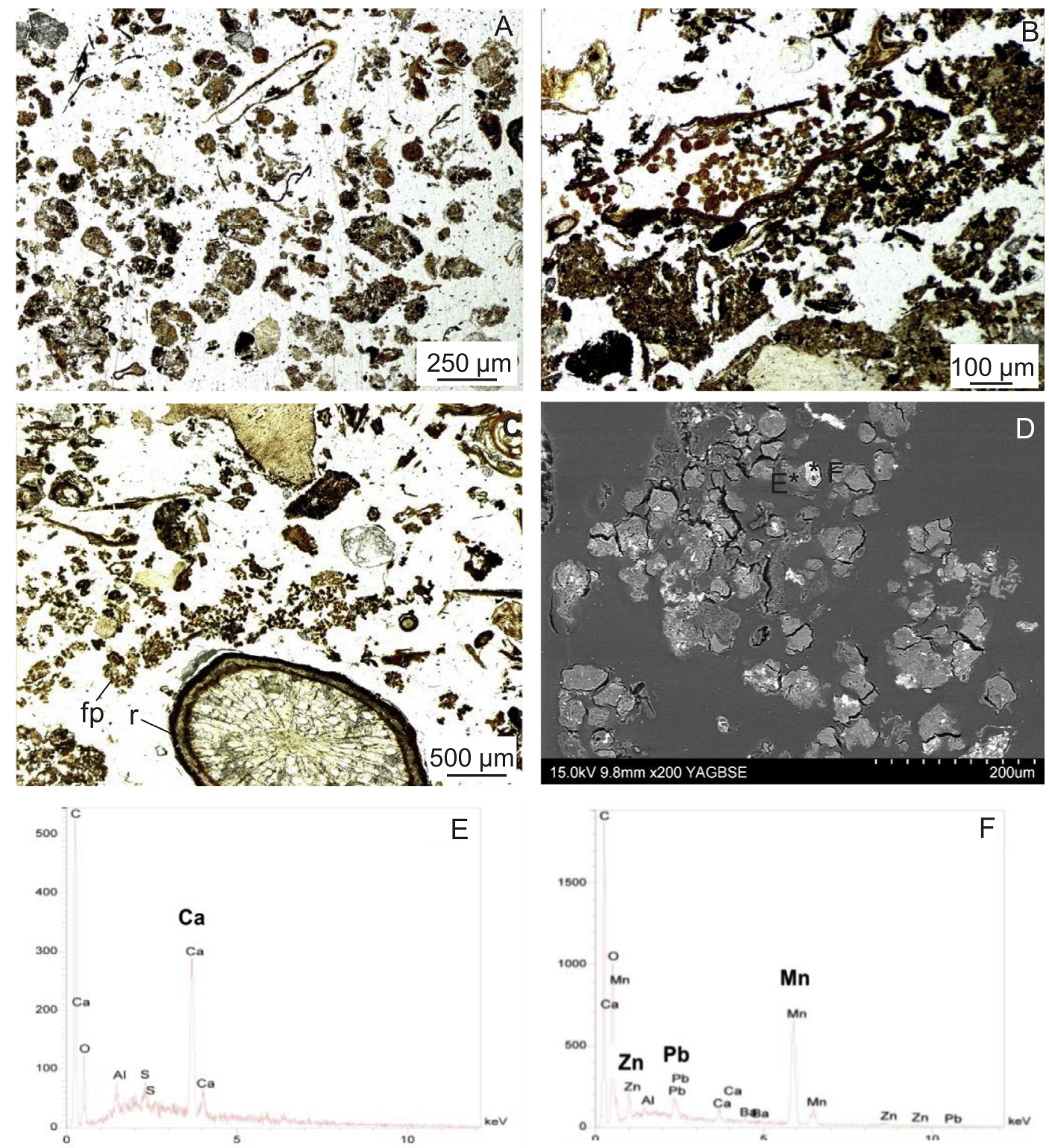

Fig. 3. Observations and analyses of organo-mineral associations due to biological activity on thin sections. (A) fecal pellets of several fauna groups; (B) mite fecal pellets in degraded plant tissue ; (C) location of mite fecal pellets analyzed by SEM-EDS ; (D) fecal pellets observed by SEM ; (E) and (F) : analyses by EDS of organic and mineral parts of the pellets. fp : fecal pellets ; $\mathrm{m}$ : mineral ; $r$ : root ;*: localization of the EDS analyses.

Table 3

Metal concentrations in three species of Diplopoda (mean \pm standard deviation).

\begin{tabular}{|c|c|c|c|c|}
\hline \multirow[t]{2}{*}{ species } & \multirow{2}{*}{$\begin{array}{l}\text { number of } \\
\text { analyzed } \\
\text { individuals }\end{array}$} & $\mathrm{Cu}$ & $\mathrm{Pb}$ & $\mathrm{Zn}$ \\
\hline & & $\mathrm{mg} \mathrm{kg}^{-1}$ & $\mathrm{mg} \mathrm{kg}^{-1}$ & $\mathrm{mg} \mathrm{kg}^{-1}$ \\
\hline $\begin{array}{l}\text { Cylindroiulus } \\
\text { punctatus }\end{array}$ & 118 & $190 \pm 57$ & $187 \pm 111$ & $447 \pm 152$ \\
\hline Julus scandinavius & 21 & $126 \pm 78$ & $167 \pm 174$ & $400 \pm 247$ \\
\hline $\begin{array}{l}\text { Polydesmus } \\
\text { angustus }\end{array}$ & 11 & $143 \pm 27$ & $137 \pm 85$ & $745 \pm 144$ \\
\hline
\end{tabular}

contaminated forest litters (Cluzeau et al., 2012). However, the slight predominance of hemiedaphic Collembola was also typical of brownfield soils (ADEME, Bioindicateurs dataset; Pérès et al., 2011). No significant effect of the soil's heavy metal concentrations $(\mathrm{Pb}, \mathrm{Zn}, \mathrm{Cd}, \mathrm{Cu})$ on the collembolan community composition was observed. Nonetheless, this did seem to be influenced by the variations in Fe soil concentrations across the site. This metal is a major element of this soil and the consequences for soil Collembola have been little documented. However, it has been shown in laboratory experiments that, contrary to $\mathrm{Mn}, \mathrm{Fe}$ could reduce the feeding activity of some species (Nottrot et al., 1987). These effects are probably species specific, and thus the Fe variability observed on the site could contribute to the structuring of the communities.

The overall microarthropod community was dominated by Collembola, as observed in some urban and industrial soils, even though forest mesofauna communities are generally dominated by Acari (Cluzeau et al., 2012; Joimel et al., 2017). However, the structure of the Acari communities, dominated by oribatid mites, is typical of forest ecosystems (Joimel, 2015).

The abundance of the macrofauna community was comparable to that in natural forests (Cluzeau et al., 2012). However the community structure showed a relatively high abundance of Diplopoda and a relative low density of earthworms, compared to natural forests or other urban and industrial soils (ADEME, Bioindicateurs dataset; Cluzeau 

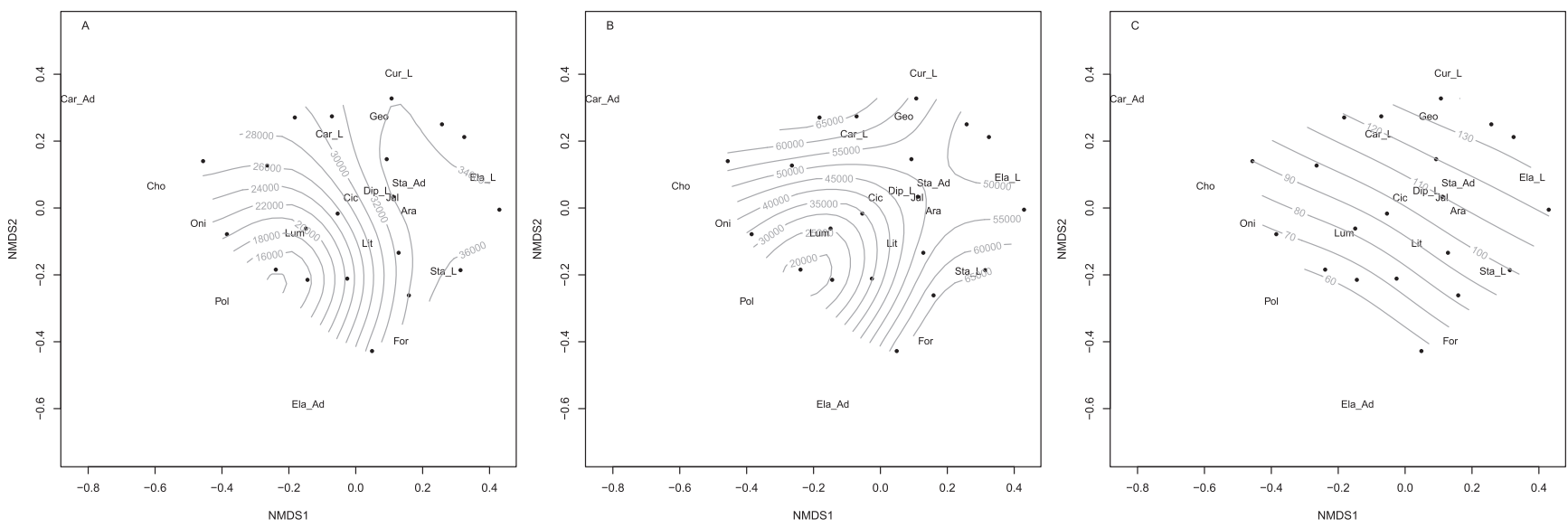

Fig. 4. Generalized additive models based on soil metal concentrations and macrofauna assemblage $(n=20)$. Gradients of soil total concentrations of Zn (A), Mn (B) and $\mathrm{Cd}(\mathrm{C})$ are indicated by gray isolines on the two-dimensional NMDS space (stress $=0.255$ ) concerning data for macrofauna taxa. Black dots represent the sampling points. Macrofauna taxa labels are Ara: Arachnidae; Car_Ad: Carabidae (adults); Car_L: Carabidae (larvae); Cho: Chordeumatidae; Cic: Cicadelidae; Cur_L: Curculionidae (larvae); Dip_L: Diptera (larvae) ; Ela_Ad: Elateridae (adults); Ela_L: Elateridae (larvae) ; For: Formicidae ; Geo: Geophilidae ; Jul: Julidae; Lit: Lithobiidae ; Lum: Lumbricidae ; Oni: Oniscidae; Pol: Polydesmidae ; Sta_Ad: Staphylinidae (adults); Sta_L: Staphylinidae (larvae).

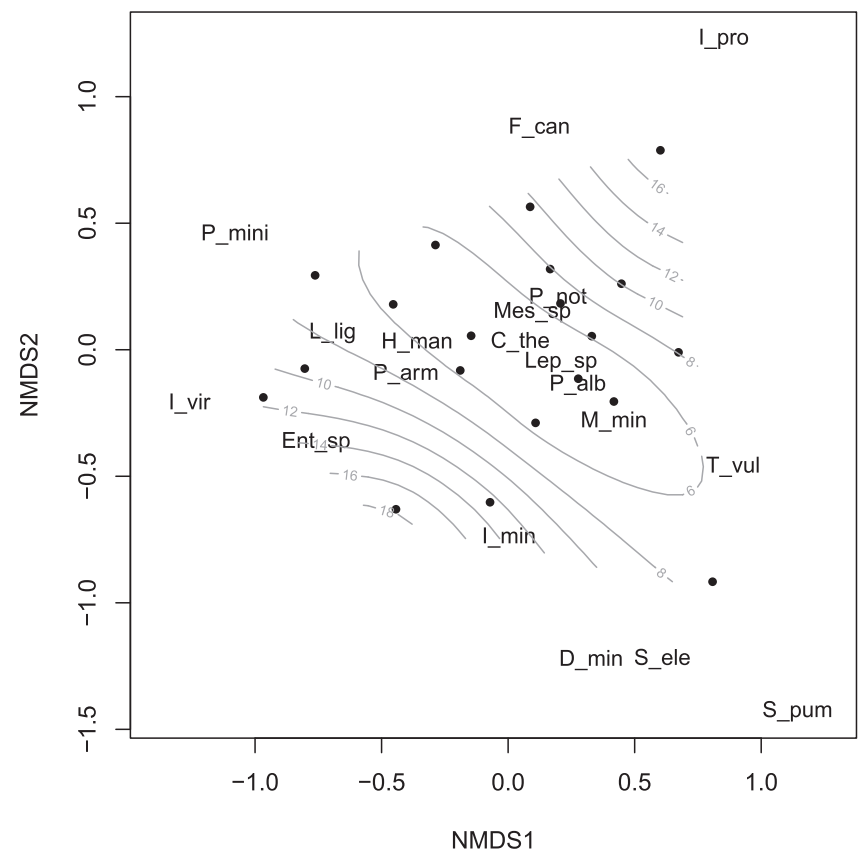

Fig. 5. Generalized additive model based on soil metal concentrations and collembolan species assemblage $(n=20)$. The gradient of soil total Fe concentration is indicated by gray isolines on the two-dimensional NMDS space (stress $=0.185$ ) concerning data for collembolan species. Black dots represent the sampling points. Species labels are defined in Table 2.

et al., 2012; Santorufo et al., 2012). The high abundance of macrofauna and of detritivorous species, especially Diplopoda, was in line with the comparative study of the macrofauna collected in pitfall traps in this forested settling pond and in analogous nearby alluvial forests (Lucisine et al., 2015). The strong dominance of the Julidae diplopod, C. punctatus could be more typical of a calcareous forest system with a slow decomposition rate (Bachelier, 1978).

The macrofauna community structure was significantly influenced by soil $\mathrm{Cd}$, $\mathrm{Mn}$ and $\mathrm{Zn}$ concentrations. As observed in soils contaminated by smelters, changes in communities may occur when metal concentrations reach a given threshold, depending on the sensitivity of the species (Gillet and Ponge, 2002). For instance, Collembola may accommodate themselves to metal pollution (Gillet and Ponge, 2003), whereas earthworm communities seem to be affected by lower concentrations of metals (Bengtsson, 1998). This could explain why earthworms and other sensitive taxa were preferentially found in the areas of the settling pond with the lowest soil $\mathrm{Zn}$ and Mn concentrations.

When looking at metal concentrations in dominant species, Cd was not detected in Diplopoda species found in the site and $\mathrm{Zn}$ and $\mathrm{Cu}$ concentrations remained comparable to those found in uncontaminated millipedes (152-827 $\mathrm{mg} \mathrm{kg}^{-1}$ for $\mathrm{Zn}$ and $33-221 \mathrm{mg} \mathrm{kg}^{-1}$ for $\mathrm{Cu}$ from literature data for millipedes used as control in laboratory experiments or sampled in reference sites; Hobbelen et al., 2004). The comparatively low Cd accumulation in millipedes suggests the presence of additional mechanisms for excluding $\mathrm{Cd}$ from deposition in the tissues of these animals. In millipedes, the exfoliation of the midgut epithelium is known to be an important mechanism for the excretion of the large amounts of metals deposited here (Seifert, 1979). In contrast, mean $\mathrm{Pb}$ accumulation was about three times higher than the maximal value of uncontaminated millipedes (0.51-62 $\mathrm{mg} \mathrm{kg}^{-1}$; Hobbelen et al., 2004), but do not seem to induce detrimental effects at the population level.

Other factors which were not tested in the study may influence the structure of the fauna communities. For instance, the low abundance or absence of earthworms observed in different anthropogenic soils was also attributed to physical properties (Burghardt, 1994). The particular physical properties (e.g. low bulk density, high water retention, presence of compacted layers; Huot et al., 2013) of this soil may have an effect on fauna communities. The quantity and quality of OM in relation to the vegetation cover are important drivers of the abundance and composition of fauna communities regarding their functions of food sources and habitat. The litter from the site has been shown to be less contaminated than the soil (Lucisine et al., 2015). Thus, as hypothesized, organic surface layers could be a favorable and protective niche for litter decomposers, such as diplopods, contrary to the earthworms living into the soil, which are subjected to a strong dermal contact and a potential ingestion of the contaminated soil.

\subsection{Potential impacts of fauna community changes on OM transformation} and metal redistribution

The observed uncommon macrofaunal community structure characterized by a relative high density of detritivores and a relative low abundance of earthworms may influence the soil formation and functioning, such as OM cycling, structure development and metal redistribution into the soil.

A relatively high accumulation of OM and the formation of a thick holorganic horizon at some places of the pond was observed. This could 
suggest a relatively slow decomposition rate as observed on other contaminated sites. However, a litter bag experiment carried out on this site revealed that the decomposition rate of $P$. tremula litter was comparable to those observed in similar natural forests on alluvial soils (Lucisine et al., 2015). This could be attributed to the high abundance of detritivores and the high availability of nutrients for microbial decomposers contributing to offset the potentially deleterious impact of metal contamination on OM decomposition (Lucisine et al., 2015). However, the relatively low abundance of earthworms can account for the limited OM incorporation into the soil and its accumulation at the surface, as observed in anthropogenic or contaminated soils (e.g. Balabane et al., 1999; Burghardt, 1994; Escarré et al., 2011; Vandecasteele et al., 2009). This could explain the high organic C concentrations in the upper layers, in addition to other abiotic factors favorable to OM stabilization related to the physical and mineralogical properties of this soil (Huot et al., 2014b).

As for the structural development, micromorphological observations showed that the activity of soil fauna, including the accumulation of fecal pellets of Isopoda and Diplopoda, has led to the development of a granular structure in the organo-mineral layer. Detritivorous invertebrates, such as oribatid mites, have been shown to ingest mineral matter and to mix it with OM within fecal pellets. However, they have a weaker effect than earthworms on the development and stability of soil structure. Fecal pellets of millipedes were shown to accumulate at the surface of post-mining sites and to remain separated from the mineral soil until colonization by the earthworms (Frouz et al., 2007). A similar trend was reported in a Zn-contaminated soil where fecal pellets of Collembola, which only have a slight effect on soil structure, were present, yet coarse organo-mineral excrements were absent due to the lack of macrofauna (Ciarkowska and Gambus, 2005). Thus, the particularity of the soil fauna community structure could affect the structural formation and stability and the extent of the mixing of organic matter from the vegetation and the mineral matter from industrial sludge.

Although rarely mentioned in the literature, this study demonstrates that metals are indeed redistributed into the soil by soil fauna. In fact, analyses of organo-mineral associations showed that metals (at least $\mathrm{Zn}$, $\mathrm{Pb}$ and $\mathrm{Cu}$ ) were integrated into the aggregates, indicating that their fate can be influenced by transfers and transformations induced by organisms. Metals ( $\mathrm{Pb}$ and $\mathrm{Zn})$ associated with mineral phases, including Mn minerals, were observed in the fecal pellets of oribatid mites, proving that, in this contaminated soil, fauna does indeed contribute to the incorporation of potentially toxic metals in organo-mineral associations and to the rearrangement of associations of these metals within the holorganic and organo-mineral layers. Even if no evidence of metal transfer in OM was observed in the pellets, the question of the impact of this rearrangement on the speciation of metals and on their mobility in the long term does arise.

\subsection{Implications in terms of site management}

Natural attenuation is mainly considered for sites contaminated by degradable substances. For heavy metals, attenuation process may be defined as a permanent immobilization within a biogeochemical zone (Peter et al., 2011). The success and the sustainability of ecological reclamation relies on the establishment of a self-sustaining ecosystem, both by stabilizing the contaminants and by restoring the ecosystem functions, such as storage, filtering, transformation of substances (nutrients and water), biodiversity reservoir, or support of biomass production (Brown and Chaney, 2016).

This study showed that a forested ecosystem with abundant and diverse soil invertebrate communities in the topsoil layers has established itself within 40-50 years on anthropogenic materials with very high metal contents, suggesting that it is possible to consider spontaneous vegetation succession as management solution for this site. The development of a quite dense and diverse vegetation cover, comparable to the ones of alluvial unpolluted forests of similar age along the Moselle river (Lucisine et al., 2015), may be attributed to the nature of the industrial materials, characterized by high nutrient concentrations, high cationic exchange capacity, high water retention capacity, nearneutral pH and a low availability of toxic metals (Huot et al., 2013). Such cover provides a significant amount of litter, which is a favorable niche for the development of the soil fauna and especially the detritivorous species, dominant in this site. In turn, this abundant community of detritivores contributes to the litter decomposition and accumulation, resulting in an enrichment of OM and nutrients at the soil surface.

Regarding the stabilization of contaminants, previous studies of this site and similar sites have shown that metal fluxes are limited in relation to the mineralogical (e.g. presence of reactive phases), chemical (e.g. slightly alkaline $\mathrm{pH}$ ) and physical (e.g. high microporosity and water retention) properties of the industrial materials (Huot et al., 2013). Nonetheless, soluble compounds (e.g. sulfates, chlorides) can be released into the nearby surface and ground waters, requiring the monitoring of their quality. The presence of a dense vegetation cover prevents any dust hazard, but the risk for human health by direct ingestion of soil particles does exist for such sites and it is recommended their access to the public be limited (Huot et al., 2015; Mansfeldt and Dohrmann, 2004).

This study revealed that soil fauna contributed to the integration of metals into organo-mineral associations in the upper horizons. Yet the extent and the effects of this redistribution on metal fate remain to be assessed. The fact that fauna communities living in upper organic layers were favoured compared to endogeic communities, may lead to the assumption that the action of soil fauna will be mainly concentrated in upper layers and direct interactions with industrial by-products and the metals they contain will be rather limited. Accumulation of organic matter at the surface and rhizospheric effects along the roots may also induce acidification and a release of organic acids, which can progressively mobilize metals in these industrial by-products. These biological processes are also involved in the maintenance of the long-term fertility, which mainly depends on the balance between losses of nutrients by drainage, inputs by mineral weathering and atmospheric deposits and uptake by plants (Ranger and Turpault, 1999).

Therefore, natural attenuation coupled with monitoring of contaminant mobility could be considered as a low-cost and valuable solution for the management of industrial settling ponds containing industrial by-products, where there are favorable physical and chemical conditions for plant growth, especially when there is no pressure for other land uses. Establishment of forested ecosystems on these former settling ponds of ironworks may provide a large range of ecosystem services, such as a biodiversity reservoir, storage of substances (C, metals), improvement of the aesthetic perception of the local landscape, as well as participating in the preservation of industrial legacy.

Further studies are needed to understand the interactions between metals, soil biota and ecosystem functions in forested contaminated ecosystems, both on the influence of changes in community structure on soil functioning and the effects of soil biota on metal cycling. As sites with high levels of metal contamination, but favorable properties for the development of plants and soil biota, former ironworks settling ponds which have spontaneously revegetated, are remarkable sites for exploring and monitoring such interactions over time and for studying the feasibility of natural attenuation as a sustainable management solution.

\section{Acknowledgements}

This work was supported by the GISFI project (www.gisfi.fr). The authors are grateful to the site owner, the Etablissement Public de la Métropole Lorraine, and the former industrial owner, ArcelorMittal, especially Patrick Charbonnier who helped us to investigate the site. Also, this work is a contribution to the Joint Lab ECOLAND (Laboratoire International Associé) established by the University of Lorraine, INRA 
and Sun Yat-sen University. The authors are thankful to the technicians of the Laboratory Soils and Environment for their most valuable inputs, particularly Alain Rakoto, Adeline Bouchard, Stéphane Colin, and JeanClaude Begin for the production of soil sections. They also thank Dr Florence Maunoury-Danger and Pr Serge Muller for the information about the vegetation as well as Clément Otterman for the analysis of soil invertebrates. The three anonymous reviewers and the editor are thanked for their helpful comments and Helen Selliez for improving the English.

\section{Appendix A. Supplementary data}

Supplementary data associated with this article can be found, in the online version, at https://doi.org/10.1016/j.apsoil.2018.08.020.

\section{References}

ADEME, Bioindicateurs, Biological tools for sustainable soils, BIOindicateurs II program, updated in 2016 .

Addison, J.A., Holmes, S.B., 1995. Comparison of forest soil microcosm and acute toxicity studies for determining effects of fenitrothion on earthworms. Ecotoxicol. Environ. Saf. 30, 127-133.

Auclerc, A., 2017. Ecosystem services provided by soils. Biodiversity. edited on behalf of IUSS Working Group SUITMA, Stuttgart pp. 213-220.

G. Bachelier La faune des sols, son ecologie et son action. Initiat.-Doc. Tech. No 381978 ORSTOM, Paris.

Balabane, M., Faivre, D., van Oort, F., Dahmani-Muller, H., 1999. Mutual effects of soil organic matter dynamics and heavy metals fate in a metallophyte grassland. Environ. Pollut. 105, 45-54.

Bengtsson, J., 1998. Which species? What kind of diversity? Which ecosystem function? Some problems in studies of relations between biodiversity and ecosystem function. Appl. Soil Ecol. 10, 191-199.

Blouin, M., Hodson, M.E., Delgado, E.A., Baker, G., Brussaard, L., Butt, K.R., Dai, J., Dendooven, L., Peres, G., Tondoh, J.E., Cluzeau, D., Brun, J.-J., 2013. A review of earthworm impact on soil function and ecosystem services: earthworm impact on ecosystem services. Eur. J. Soil Sci. 64, 161-182.

Bradshaw, A., 2000. The use of natural processes in reclamation - advantages and difficulties. Landsc. Urban Plan. 51, 89-100.

Bretfeld, G., 1999. Synopses on Palearctic Collembola. Symphypleona-Abh Ber Naturkundemus Görlitz 71, 1-318.

Brown, S.L., Chaney, R.L., 2016. Use of amendments to restore ecosystem function to metal mining-impacted sites: tools to evaluate efficacy. Curr. Pollut. Rep. 2, 91-102.

Bullock, P., Fedoroff, N., Jongerius, A., Stoops, G., Tursina, T., 1985. Handbook for soil thin section description. Waine Research.

Burghardt, W., 1994. Soils in urban and industrial environments. Z. Für Pflanzenernähr. Bodenkd. 157, 205-214.

Caruso, T., Migliorini, M., Bucci, C., Bargagli, R., 2009. Spatial patterns and autocorrelation in the response of microarthropods to soil pollutants: The example of oribatid mites in an abandoned mining and smelting area. Environ. Pollut. 157, 2939-2948.

Chaussidon, C., 1990. Analyse chimique du sol et références géochimiques, BRGM report No. R 31979 LOR 4S 91 (in French).

Ciarkowska, K., Gambus, F., 2005. Micromorphometric characteristics of upper layers of soils contaminated by heavy metals in the vicinity of a zinc and lead ore plant. Pol. J. Environ. Stud. 14, 417-421.

Cluzeau, D., Guernion, M., Chaussod, R., Martin-Laurent, F., Villenave, C., Cortet, J. Ruiz-Camacho, N., Pernin, C., Mateille, T., Philippot, L., Bellido, A., Rougé, L., Arrouays, D., Bispo, A., Pérès, G., 2012. Integration of biodiversity in soil quality monitoring: Baselines for microbial and soil fauna parameters for different land-use types. Eur. J. Soil Biol. 49, 63-72.

Cortet, J., Griffiths, B.S., Bohanec, M., Demsar, D., Andersen, M.N., Caul, S., E Birch, A.N., Pernin, C., Tabone, E., de Vaufleury, A., Ke, X., Krogh, P.H., 2007. Evaluation of effects of transgenic Bt maize on microarthropods in a European multi-site experiment. Pedobiologia 51207, 218.

Darmendrail, D., Baize, D., Barbier, J., Freyssinet, P., Mouvet, C., Salpéteur, I., Wavrer, P., 2000. Fond géochimique naturel: État des connaissances à l'échelle nationale, BRGM report No. BRGM/RP-50158-FR (in French).

Escarré, J., Lefèbvre, C., Raboyeau, S., Dossantos, A., Gruber, W., Marel, J.C.C., Frérot, H., Noret, N., Mahieu, S., Collin, C., van Oort, F., 2011. Heavy metal concentration survey in soils and plants of the les malines mining district (southern france): implications for soil restoration. Water. Air. Soil Pollut. 216, 485-504.

Frouz, J., Pižl, V., Tajovský, K., 2007. The effect of earthworms and other saprophagous macrofauna on soil microstructure in reclaimed and un-reclaimed post-mining sites in Central Europe. Eur. J. Soil Biol. 43, S184-S189.

Frouz, J., Prach, K., Pizl, V., Hanel, L., Stary, J., Tajovsky, K., Materna, J., Balik, V., Kalcik, J., Rehounkova, K., 2008. Interactions between soil development, vegetation and soil fauna during spontaneous succession in post mining sites. Eur. J. Soil Biol. 44, 109-121.

Gillet, S., Ponge, J.F., 2002. Humus forms and metal pollution in soil. Eur. J. Soil Sci. 53, $529-540$.
Gillet, S., Ponge, J.-F., 2003. Changes in species assemblages and diets of Collembola along a gradient of metal pollution. Appl. Soil Ecol. 22, 127-138.

Gisin, H., 1960. Collembolen fauna Europas, Museum d'Histoire Naturelle. ed. Geneve.

Hobbelen, P.H.F., Koolhaas, J.E., Van Gestel, C.A.M., 2004. Risk assessment of heavy metal pollution for detritivores in floodplain soils in the Biesbosch, the Netherlands, taking bioavailability into account. Environ. Pollut. 129, 409-419.

Hothorn, T., Zeileis, A., Farebrother, R.W., Cummins, C., Millo, G., 2017. Package 'Imtest'. Testing Linear Regression Models. 0.9-35 in R on February 11, 2017.

Huot, H., Simonnot, M.-O., Marion, P., Yvon, J., Donato, P.D., Morel, J.-L., 2013. Characteristics and potential pedogenetic processes of a Technosol developing on iron industry deposits. J. Soils Sediments 13, 555-568.

Huot, H., Simonnot, M.O., Watteau, F., Marion, P., Yvon, J., De Donato, P., Morel, J.L., 2014a. Early transformation and transfer processes in a Technosol developing on iron industry deposits. Eur. J. Soil Sci. 65, 470-484.

Huot, H., Faure, P., Biache, C., Lorgeoux, C., Simonnot, M.-O., Morel, J.L., 2014b. A Technosol as archives of organic matter related to past industrial activities. Sci. Total Environ. 487, 389-398.

Huot, H., Séré, G., Charbonnier, P., Simonnot, M.-O., Morel, J.-L., 2015. Lysimeter monitoring as assessment of the potential for revegetation to manage former iron industry settling ponds. Sci. Total Environ. 526, 29-40.

Joimel, S., 2015. Biodiversité et caractéristiques physicochimiques des sols de jardins associatifs urbains français. Université de Lorraine, Nancy (in French).

Joimel, S., Schwartz, C., Hedde, M., Kiyota, S., Krogh, P.H., Nahmani, J., Pérès, G., Vergnes, A., Cortet, J., 2017. Urban and industrial land uses have a higher soil biological quality than expected from physicochemical quality. Sci. Total Environ. 584-585, 614-621.

Khalil, M.A., Janssens, T.K., Berg, M.P., van Straalen, N.M., 2009. Identification of metalresponsive oribatid mites in a comparative survey of polluted soils. Pedobiologia 52, 207-221.

Krantz, G.W., 1978. A manual of acarology, Second ed. Oregon State University Book Stores Inc, Corvallis.

Krantz, G.W., Walter, D.E., 2009. A Manual of Acarology, Third edition. Texas Tech University Press, Lubbock, USA.

Lanno, R., Wells, J., Conder, J., Bradham, K., Basta, N., 2004. The bioavailability of chemicals in soil for earthworms. Ecotoxicol. Environ. Saf. 57, 39-47.

Lucisine, P., Lecerf, A., Danger, M., Felten, V., Aran, D., Auclerc, A., Gross, E.M., Huot, H., Morel, J.-L., Muller, S., Nahmani, J., Maunoury-Danger, F., 2015. Litter chemistry prevails over litter consumers in mediating effects of past steel industry activities on leaf litter decomposition. Sci. Total Environ. 537, 213-224.

Mansfeldt, T., Dohrmann, R., 2004. Chemical and mineralogical characterization of blastfurnace sludge from an abandoned landfill. Environ. Sci. Technol. 38, 5977-5984.

Marra, G.P., Wood, S.N., 2011. Practical variable selection for generalized additive models. Comput. Stat. Data Analysis. 55, 2372-2387.

Nahmani, J., Lavelle, P., 2002. Effects of heavy metal pollution on soil macrofauna in a grassland of Northern France. Eur. J. Soil Biol. 38, 297-300.

Nahmani, J., Hodson, M.E., Black, S., 2007. A review of studies performed to assess metal uptake by earthworms. Environ. Pollut. 145, 402-424.

Niemeyer, J.C., Nogueira, M.A., Carvalho, G.M., Cohin-De-Pinho, S.J., Outeiro, U.S., Rodrigues, G.G., da Silva, E.M., Sousa, J.P., 2012. Functional and structural parameters to assess the ecological status of a metal contaminated area in the tropics. Ecotoxicol. Environ. Saf. 86, 188-197.

Nottrot, F., Joosse, E.N.G., van Straalen, N.M., 1987. Sublethal effects of iron and manganese soil pollution on Orchesella cincta (Collembola). Pedobiologia 45-53.

Oksanen J., 2016. Vegan: ecological diversity. Processed with vegan 2.4-1 in R Under development (unstable) (2016-09-06 r71220) on September 7, 2016.

Pérès, G., Vandenbulcke, F., Guernion, M., Hedde, M., Beguiristain, T., Douay, F., Houot, S., Piron, D., Richard, A., Bispo, A., Grand, C., Galsomies, L., Cluzeau, D., 2011. Earthworm indicators as tools for soil monitoring, characterization and risk assessment. An example from the national Bioindicator programme (France). Pedobiologia, in: 9th International Symposium on Earthworm EcologyXalapa, Veracruz, Mexico, 5th-10th September 2010 54, Supplement, S77-S87.

Peter, A., Held, T., Hüsers, N., Swartjes, F.A., 2011. Natural Attenuation. In: Dealing with Contaminated Sites. Springer, Dordrecht, pp. 979-1014.

Potapov, M., Dunger, W., 2001. Synopses on Palaearctic Collembola: Isotomidae. Staatliches Museum für Naturkunde Görlitz.

Prach, K., Hobbs, R.J., 2008. Spontaneous succession versus technical reclamation in the restoration of disturbed sites. Restor. Ecol. 16, 363-366.

R Core Team, 2013. R: a language and environment for statistical computing, Vienna, Austria. Available online at http://www.R-project.org.

Rameau, J.C., Mansion, D., Dumé, G., Timbal, J., Lecointe, A., Dupont, P., Keller, R., 1989. Flore Forestière Française, Guide écologique illustré. Tome I: plaines et collines. Institut pour le développement forestier, Paris (in French).

Ranger, J., Turpault, M.-P., 1999. Input-output nutrient budgets as a diagnostic tool for sustainable forest management. For. Ecol. Manag. 122, 139-154.

Santorufo, L., Van Gestel, C.A.M., Rocco, A., Maisto, G., 2012. Soil invertebrates as bioindicators of urban soil quality. Environ. Pollut. 161, 57-63.

Santorufo, L., Cortet, J., Nahmani, J., Pernin, C., Salmon, S., Pernot, A., Morel, J.L., Maisto, G., 2015. Responses of functional and taxonomic collembolan community structure to site management in Mediterranean urban and surrounding areas. Eur. J. Soil Biol. 70, 46-57.

Schwartz, C., Florentin, L., Charpentier, D., Muzika, S., Morel, J.-L., 2001. Le pédologue en milieux industriels et urbains. I. Sols d'une friche industrielle. Etude Gest. Sols 8 , $135-148$.

Seifert, G., 1979. Considerations about the evolution of excretory organs in terrestrial arthropods. Academic Press.

Selonen, S., Liiri, M., Setälä, H., 2014. Can the soil fauna of boreal forests recover from 
lead-derived stress in a shooting range area? Ecotoxicology 23, 437-448.

Sizmur, T., Hodson, M.E., 2009. Do earthworms impact metal mobility and availability in soil? - a review. Environ. Pollut. 157, 1981-1989.

Syrek, D., Weiner, W.M., Wojtylak, M., Olszowska, G., Kwapis, Z., 2006. Species abundance distribution of collembolan communities in forest soils polluted with heavy metals. Appl. Soil Ecol. 31, 239-250.

Vandecasteele, B., Quataert, P., Genouw, G., Lettens, S., Tack, F.M.G., 2009. Effects of willow stands on heavy metal concentrations and top soil properties of infrastructure spoil landfills and dredged sediment-derived sites. Sci. Total Environ. 407, 5289-5297. 